Article

\title{
Gelatin Nanoparticles-HPMC Hybrid System for Effective Ocular Topical Administration of Antihypertensive Agents
}

\author{
Sergio Esteban-Pérez ${ }^{1,2,3}$ [D, Vanessa Andrés-Guerrero ${ }^{1,2,3}$ [ , José Javier López-Cano ${ }^{1,2,3}$, \\ Irene Molina-Martínez ${ }^{1,2,3} \mathbb{D}$, Rocio Herrero-Vanrell ${ }^{1,2,3}$ and Irene Bravo-Osuna ${ }^{1,2,3, *}$ \\ 1 Innovation, Therapy and Pharmaceutical Development in Ophthalmology (InnOftal) Research Group, \\ UCM 920415, Department of Pharmaceutics and Food Technology, Faculty of Pharmacy, Complutense \\ University of Madrid, Plaza Ramón y Cajal s/n, 28040 Madrid, Spain; seresteb@ucm.es (S.E.-P.); \\ vandres@ucm.es (V.A.-G.); josejavl@ucm.es (J.J.L.-C.); iremm@ucm.es (I.M.-M.); rociohv@ucm.es (R.H.-V.) \\ 2 Sanitary Research Institute of the San Carlos Clinical Hospital (IdISSC) San Carlos Clinical Hospital, \\ Calle Profesor Martín Lagos, s/n, 28040 Madrid, Spain \\ 3 Ocular Pathology National Net (OFTARED) of the Institute of Health Carlos III, Calle Profesor Martín Lagos, \\ s/n, 28040 Madrid, Spain \\ * Correspondence: ibravo@ucm.es
}

Received: 26 February 2020; Accepted: 24 March 2020; Published: 28 March 2020

\begin{abstract}
The increment in ocular drug bioavailability after topical administration is one of the main challenges in pharmaceutical technology. For several years, different strategies based on nanotechnology, hydrogels or implants have been evaluated. Nowadays, the tolerance of ophthalmic preparations has become a critical issue and it is essential to the use of well tolerated excipients. In the present work, we have explored the potential of gelatin nanoparticles (GNPs) loaded with timolol maleate (TM), a beta-adrenergic blocker widely used in the clinic for glaucoma treatment and a hybrid system of TM-GNPs included in a hydroxypropyl methylcellulose (HPMC) viscous solution. The TM- loaded nanoparticles (mean particle size of $193 \pm 20 \mathrm{~nm}$ and drug loading of $0.291 \pm 0.019$ $\mathrm{mg} \mathrm{TM} / \mathrm{mg}$ GNPs) were well tolerated both in vitro (human corneal cells) and in vivo. The in vivo efficacy studies performed in normotensive rabbits demonstrated that these gelatin nanoparticles were able to achieve the same hypotensive effect as a marketed formulation $(0.5 \% \mathrm{TM})$ containing a 5 -fold lower concentration of the drug. When comparing commercial and TM-GNPs formulations with the same TM dose, nanoparticles generated an increased efficacy with a significant $(p<0.05)$ reduction of intraocular pressure (IOP) (from $21 \%$ to $30 \%$ ) and an augmentation of 1.7-fold in the area under the curve $(\mathrm{AUC})_{(0-12 \mathrm{~h})}$. On the other hand, the combination of timolol-loaded nanoparticles (TM $0.1 \%$ ) and the viscous polymer HPMC $0.3 \%$, statistically improved the IOP reduction up to $30 \%(4.65 \mathrm{mmHg})$ accompanied by a faster time of maximum effect $\left(t_{\max }=1 \mathrm{~h}\right)$. Furthermore, the hypotensive effect was extended for four additional hours, reaching a pharmacological activity that lasted $12 \mathrm{~h}$ after a single instillation of this combination, and leading to an $\mathrm{AUC}_{(0-12 \mathrm{~h})} 2.5$-fold higher than the one observed for the marketed formulation. According to the data presented in this work, the use of hybrid systems that combine well tolerated gelatin nanoparticles and a viscous agent could be a promising alternative in the management of high intraocular pressure in glaucoma.
\end{abstract}

Keywords: gelatin nanoparticles; glaucoma; HPMC; timolol maleate; topical ocular drug delivery; nanotechnology 


\section{Introduction}

Glaucoma is considered as a group of ocular chronic disorders characterized by a distinctive neuropathy that leads to a progressive asymptomatic visual field loss. One of the main risk factors in glaucoma development is the high intraocular pressure (IOP) [1,2]. Generally, the maintained increase of IOP is triggered by the accumulation of aqueous humour in the anterior chamber of the eye due to a distortion between its production and its outflow through the trabecular meshwork. This high pressure is transmitted to the posterior segment of the eye and to the retina and optic nerve head promoting the progressive death of the retinal ganglion cells (RGCs) and thus, inducing the loss of vision [3].

Currently, lowering of IOP is the only therapeutic measure for glaucoma management. Glaucoma treatments consist of IOP modulation by either reducing the aqueous humour production or enhancing its outflow. Among the main therapeutic agents, non-selective $\beta$ - antagonists such as timolol maleate (TM), betaxolol or carteolol are widely employed as first-line therapy because of their efficacy at reducing IOP [4]. These drugs reduce aqueous humour by inhibition of AMPc synthesis via antagonization of the $\beta$-adrenergic receptors present in the ciliary body cells [5].

Topical ocular administration is the chosen route for IOP management. Eye drops can be straightforwardly instilled on the ocular surface in a comfortable way for patients. However low ocular bioavailability, typically lower than $5 \%$, is generally achieved for classical eye drops formulations $[6,7]$. This is due to the presence of ocular protective barriers and precorneal tear clearance that reduce the drug residence time on the ocular surface. Furthermore, most active compounds present poor corneal penetration [8,9]. This is the reason why repeated administrations and high drug concentrations are required in order to obtain a therapeutic effect [10]. Unfortunately, in many cases repeated administrations lead to low patient compliance and thus, therapeutic failure happens [11]. Moreover, part of the lost formulation can be drained through the nasolacrimal channel, reaching the bloodstream and provoking undesirable systemic effects. For example, TM has been related to different systemic adverse reactions when eye drops are administered in a chronical way. Adverse effects such as cardiac effects, bronchospasm or syncope among others have typically been associated with chronical treatments with this active compound $[9,12,13]$.

The development of new formulations enhancing drug permeation, bioavailability and safety profile after ocular instillation has become one of the most important challenges in pharmaceutical technology in recent years [14-16]. Several novel drug delivery systems have been developed like nanoparticles, microparticles, microemulsions, hydrogels or contact lenses among others, to achieve more effective therapies [17-21]. However, it is mandatory to keep always in mind that all excipients used must be highly compatible with ocular tissues [22]. Most efforts that have been made focused on increasing the retention time of formulations, and the contained drug, on the ocular surface as an initial step for the passive transport of the active compounds through the cornea $[8,20,23]$. An effective method to retain the formulation on the ocular surface is the addition of polymers able to increase the formulation viscosity and/or its mucoadhesion, such as gelatin, chitosan, hydroxypropyl methylcellulose (HPMC), gellan, carboxy methylcellulose (CMC), hyaluronic acid, polyacrylate acids, and xanthan gums among others. This strategy partially avoids the ocular surface clearance produced by the tearing and blinking reflex [24-28]. In fact, several authors have successfully explored the use of the polysaccharide HPMC in this context [29-31]. Furthermore, HPMC is widely employed as comfort agent for dry eye disease (DED) due to its pseudoplastic behaviour and high tolerance [32]. Because of the chronic nature of glaucoma and the need of repeated instillations, many patients suffer also DED over time, due to the continuous contact with preservatives and even with some drugs such as timolol maleate [33]. Studies from our research group have demonstrated that the inclusion of HPMC in the formulation increases its in vitro and in vivo tolerance in experimental animals [24].

As mentioned before, another interesting approach to increase the drug retention time on the ocular surface and, hence, its ocular bioavailability, is the use of nanoparticles [22,34,35]. Due to their nanometric range and large surface area, they seem to have an enhanced capacity to be entrapped over the precorneal film and even to permeate the ocular surface epithelium [36]. In addition, nanoparticles 
can protect the drug from degradation and modulate its release in a controlled manner [37,38]. Several biopolymers have been evaluated to prepare nanoparticles for ocular instillation, such as polylactic-co-glycolic acid [39,40], chitosan [37,41] or hyaluronic acid [42,43]. In this sense, gelatin is a widely employed material due to its biocompatible and biodegradable characteristics [44,45]. It has mucoadhesive properties that can prolong nanoparticles precorneal residence time [46,47]. The first experiments with gelatin nanoparticles for topical administration originate from 1989, in which authors employed pilocarpine for miotic purposes [48]. Later, some researchers developed nanoparticles for topical administration that contained pilocarpine and hydrocortisone [49]. More recently, other authors have explored the use of gelatin nanoparticles with other active agents such as timolol maleate [50] or moxifloxacin [51]. Nowadays, the rise in genetic therapies has also shown that gelatin nanosystems are safe and efficient vectors for gene delivery in ophthalmology [52].

The aim of the present work is to evaluate the combination of two technological strategies to increase the ocular bioavailability of timolol maleate (TM), an ocular hypotensive drug widely used in the clinic for glaucoma treatment. To that end, we have explored the potential of a hybrid system composed by gelatin nanoparticles loaded with TM, included in a hydroxypropyl methylcellulose viscous solution. Timolol-loaded gelatin nanoparticles (GNPs) were prepared by an ethanol-water solvent displacement method that avoids the use of hazardous components during the process. Formulations were physicochemically characterized. In order to mimic ocular surface conditions, the in vitro release tests were performed with proteases or metalloproteinase-2 (MMP-2) in the release media, which are enzymes typically present in the eye of glaucomatous patients [53-55]. These results were compared with conventional release studies performed with plain PBS solutions. After in vitro (human corneal epithelium cells) and in vivo (rabbits) tolerance studies, the hypotensive efficacy of the novel formulations with different TM concentrations was evaluated in rabbits and compared with the administration of a timolol maleate marketed formulation under the same conditions.

\section{Materials and Methods}

\subsection{Materials}

Gelatin from bovine skin type B (gel strength $225 \mathrm{~g}$ Bloom), protease from Streptomyces griseus, $\mathrm{NaOH}, \mathrm{MMP}-2$ human recombinant, glyoxal solution $40 \%$ and glycine were purchased from Sigma-Aldrich (St. Louis, MO, USA). TM and HPMC were obtained from Fagron (Barcelona, Spain). Absolute ethanol, trifluoroacetic acid and acetonitrile were acquired from Panreac (Madrid, Spain). Dialysis membrane with a molecular weight cut-off $3500 \mathrm{~g} / \mathrm{mol}$ was provided by Medicel Membranes (London, UK). Timabak 0.5\% (Thea Laboratories; Madrid, Spain) was purchased in a local pharmacy store. Ultrapure milli-Q water was used in all the studies. All other chemicals were reagent grade and used as received.

\subsection{TM HPLC Determination}

The TM high-performance-liquid-chromatography (HPLC) determination was performed as described by Boiero et al. [56] with slight modifications. The HPLC system was composed by a separation module Waters Alliance 2695 and a Waters photodiode array 2996 (Barcelona, Spain). The wavelength was set at $297 \mathrm{~nm}$. Mobile phase was composed by $0.05 \%(\mathrm{v} / \mathrm{v})$ trifluoroacetic acid in water and $0.05 \%(\mathrm{v} / \mathrm{v})$ trifluoroacetic acid in acetonitrile (40:60) at a flow rate of $1 \mathrm{~mL} / \mathrm{min}$. The analytical column was Hypersil silica column $(250 \times 4 \mathrm{~mm} 5 \mu \mathrm{m}$ particle size). Data acquisition and processing were performed by Empower 3 software (Waters, Barcelona, Spain).

\subsection{Elaboration of Gelatin Nanoparticles (GNPs) and Eye Drops Formulations}

GNP formulations were developed employing a modified ethanol-water solvent displacement method as described by Amiji and co-workers [57]. Briefly, $200 \mathrm{mg}$ type B gelatin (Bloom 225) was dissolved in $20 \mathrm{~mL}$ of ultrapure water at $37^{\circ} \mathrm{C}$, then TM $(200 \mathrm{mg})$ was dissolved in the so-formed 
gelatin solution and $\mathrm{pH}$ was adjusted to 7.0 using a solution of $\mathrm{NaOH} 0.2 \mathrm{M}$. Nanoparticles were created by the ethanol-induced desolvation process. Briefly, the gelatinous solution was added dropwise to $\sim 65 \mathrm{~mL}$ of absolute ethanol under permanent stirring (600 rpm). The resulting nanoparticulate structures were crosslinked with $1 \mathrm{~mL}$ of $4 \%$ glyoxal. After $2 \mathrm{~min}$ of contact, unreacted glyoxal groups were blocked by $5 \mathrm{~mL}$ of glycine $1 \mathrm{mM}$. Later, the resulting suspension was dialyzed overnight against 5L of ultrapure water to warrant the elimination of any soluble compound. Finally, the nanoparticle suspension was freeze-dried to obtain a free-flowing product.

Eye drops formulations were prepared by a simple suspension of nanoparticles in PBS isotonized with $\mathrm{NaCl}$ ( $\mathrm{pH}$ 7.4). No aggregation was observed in any of the formulations prepared. In the case of the hybrid system proposed, timolol maleate loaded nanoparticles were suspended in HPMC 0.3\% solution in the previous mentioned media.

Formulations have been coded as "GNP" for blank gelatin nanoparticles and "TM-GNP" for timolol-loaded gelatin nanoparticle formulations as follows: TM-GNP XX (TM YY \%). Where XX is the concentration $(\mathrm{mg} / \mathrm{mL})$ of nanoparticles employed and $Y Y$ is \% TM $(\mathrm{w} / \mathrm{w})$ for each formulation. Scheme 1 represents a general structure of TM and the gelatin nanoparticles-HPMC hybrid system proposed in this work.

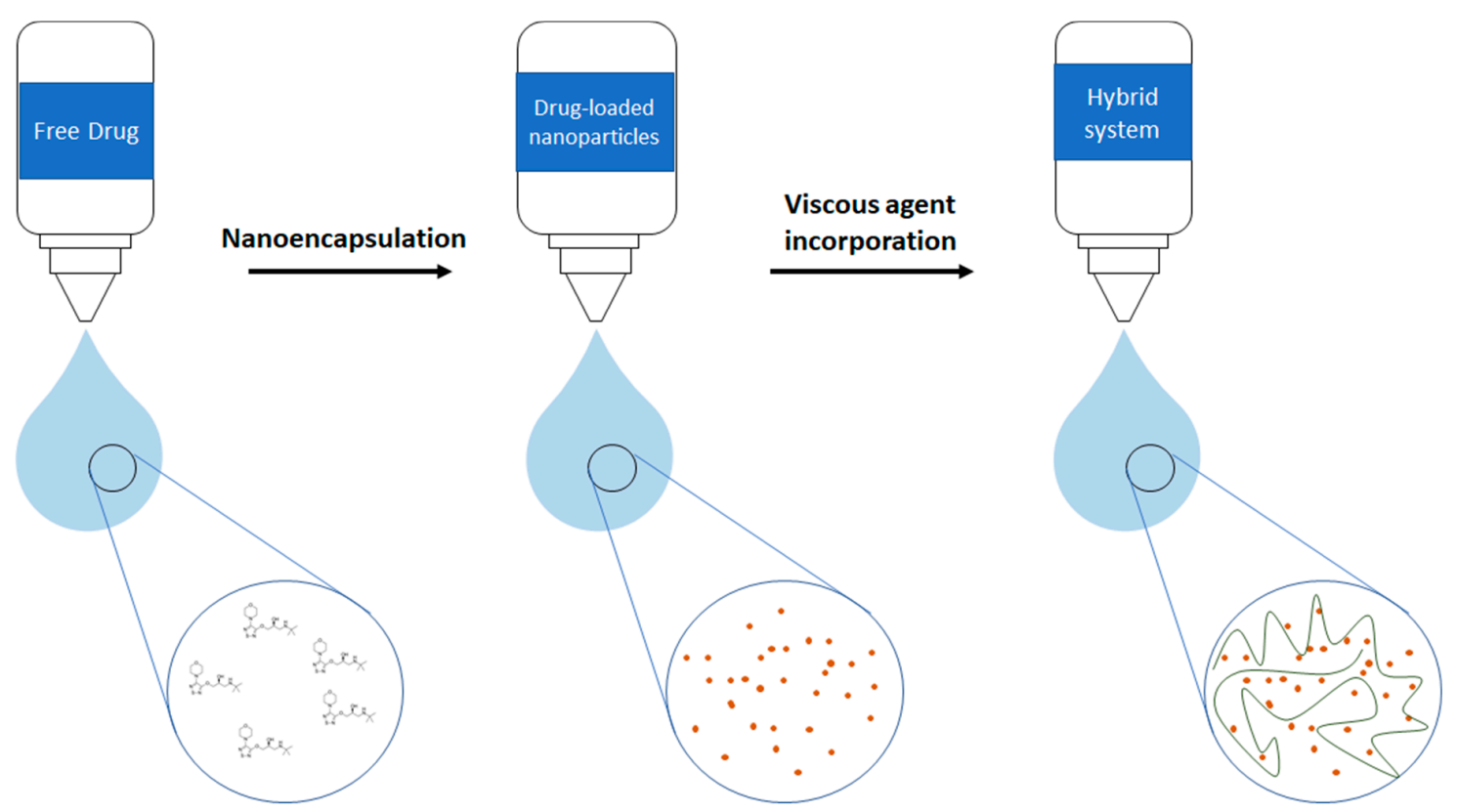

Scheme 1. General structure of timolol maleate (TM) and the gelatin nanoparticles-hydroxypropyl methylcellulose (HPMC) hybrid system.

2.4. Measurement of Mean Particle Size, Particle Size Distribution, Zeta Potential and Polydispersity Index of the TM-GNP

The mean particle size, particle size distribution and polydispersity index of nanoparticles were measured after the resuspension of the freeze-dried product in ultrapure water and Z-potential after PBS dispersion, using the dynamic light scattering technique with the instrument Malvern Zetasizer (Malvern, Worcestershire, UK). Determinations were assessed by triplicate. PDI value was determined using the following equation:

$$
\mathrm{PDI}=\left(\frac{\sigma}{D}\right)^{2}
$$

where $D$ is the mean diameter of the GNPs and the $\sigma$ is the standard deviation [58]. 


\subsection{Transmission Electron Microscopy}

GNP and TM-GNP were observed using JEOL TEM 1010 transmission electron microscopy. For this purpose, $1 \mathrm{mg} / \mathrm{mL}$ of resuspended nanoparticulate formulations was drop-casted onto a copper grid (Electron Microscopic Sciences; Aname; Rioja, Spain) and, after $30 \mathrm{~s}$ of incubation, the copper grid with the nanoparticles was dropped on a $2 \%$ uranyl acetate (Merck; Madrid, Spain) solution as a contrast imaging agent before observation.

\subsection{Determination of TM Encapsulation Efficiency}

In order to determine the amount of hypotensive drug encapsulated in TM-GNPs $(\mathrm{n}=13), 2 \mathrm{mg}$ of nanoparticles were suspended in a solution of protease $(0.2 \mathrm{mg} / \mathrm{mL})$ in PBS and incubated at $37^{\circ} \mathrm{C}$ for $20 \mathrm{~min}$ to promote the nanoparticle digestion. Then, the clear solution was filtered through a 0.22 micrometers filter and thus, analyzed by HPLC according to Section 2.2.

\subsection{In Vitro Release Study}

The release media employed for in vitro release assays was prepared with PBS isotonized with $\mathrm{NaCl}$. The $\mathrm{pH}$ measurement of PBS was performed with a $\mathrm{pH}$-meter (model 230, Mettler, Barcelona, Spain) equipped with a microelectrode (InLab, Mettler, Barcelona, Spain) resulting in a value of 7.4, similar to the precorneal film $\mathrm{pH}$ [59].

An amount of TM-GNP to reach $5 \mathrm{mg} / \mathrm{mL}$ of TM (equivalent concentration as manufactured formulation) was reconstituted in $1 \mathrm{~mL}$ of PBS with or without protease (60 ng/mL) or MMP-2 $(60 \mathrm{ng} / \mathrm{mL})(\mathrm{n}=4)$ and incorporated to a Float-A-Lyzer device (molecular weight cut-off 5,000 g/mol). The device was then submerged in a tube with $12 \mathrm{~mL}$ of PBS. The study was performed in a shaking bath at $33{ }^{\circ} \mathrm{C}$ and $100 \mathrm{rpm}$. At pre-determined times $(0.5,3,6,12,24,48,72$ and $96 \mathrm{~h}), 12 \mathrm{~mL}$ of release media were taken and used for the quantification of TM, then, the same volume of fresh media was added to continue the study.

The drug loading value obtained in the determination of encapsulation efficiency assay previously described in Section 2.6 was considered as the $100 \%$ of drug that can potentially be released from the nanoparticles.

\subsection{In Vitro Tolerance Studies}

Human corneal cells (HCEpiC) (Innoprot; Bizkaia, Spain) were grown in the corneal epithelial cell medium supplemented with Human Corneal Growth Factors (HCGF) and $50 \mathrm{IU} / \mathrm{mL}$ penicillin, $50 \mu \mathrm{g} / \mathrm{mL}$ streptomycin, containing $5 \mathrm{mM}$ glucose (Sigma Aldrich). Cells were incubated at $37^{\circ} \mathrm{C}$ in a $5 \%$ carbon dioxide atmosphere under $95 \%$ humidity and experiments were performed under passages 5-10. Cells were grown as monolayers and were employed after becoming confluent. Twenty-four-well plates and cells at a $2 \times 10^{4}$ cells/well concentration were seeded for the in vitro tolerance study. The MTT ((3-(4,5-Dimethylthiazol-2-yl)-2,5-Diphenyltetrazolium Bromide) (Sigma Aldrich) cytotoxicity assay was used $[15,60]$. MTT technique is widely employed for assessing toxicity in novel developed systems [14,15]. Cells were exposed to gelatin (30 mg/mL), GNP (10 mg/mL and $30 \mathrm{mg} / \mathrm{mL})$ and TM-GNP $(10 \mathrm{mg} / \mathrm{mL}, 20 \mathrm{mg} / \mathrm{mL}$ and $30 \mathrm{mg} / \mathrm{mL})$ at different exposure times $(1 \mathrm{~h}, 4 \mathrm{~h}$ and $24 \mathrm{~h})$. Then MTT $(5 \mathrm{mg} / \mathrm{mL})$ reactive was added and incubated for $4 \mathrm{~h}$. After the incubation period, dimethyl sulfoxide was added to solubilize the formazan salts. The absorbance was read at $570 \mathrm{~nm}$ with background subtraction at $690 \mathrm{~nm}$.

Benzalkonium chloride (BAK) $0.005 \%$ was used as a positive cytotoxicity control [61]. Untreated cells were used as negative control. The percentage of viable cells was determined in relation to control cells. To that end, the optical density of control cells was divided by the optical density of the treated cells and multiplied per 100 and thus, the tolerance value was obtained. 


\subsection{Animals}

Healthy normotensive male New Zealand rabbits with an average weight of $3 \mathrm{~kg}$ (Granja San Bernardo, Navarra, Spain) were kept at an animal house of the Complutense University of Madrid. Animals were housed in separated cages with food, water ad libitum and were maintained in a controlled environment at $25^{\circ} \mathrm{C}$ with a 12-h on/off light cycle. All procedures herein complied with the Association for Research in Vision and Ophthalmology (ARVO) Statement for the Use of Animals in Ophthalmic and Vision Research and were also in accordance with the European Communities Council Directive (2010/63/UE of the European Parliament and of the Council of 22 September 2010 on the protection of animals used for scientific purposes) and approved by the Complutense University of Madrid and Autonomous Community of Madrid (PROEX 316/16 January 25 2017).

\subsection{In Vivo Acute Tolerance Tests}

In vivo tolerance studies were performed in rabbits $(\mathrm{n}=6)$. According to the protocol, $25 \mu \mathrm{l}$ of a GNP suspension ( $30 \mathrm{mg} / \mathrm{mL}$ ) was administered in the right eye (OD) of the rabbit and $25 \mu \mathrm{l}$ of an isotonic saline solution in the left eye (OI) every $30 \mathrm{~min}$ for six hours. The macroscopic evaluation was assessed before the beginning the study and at 3,6 and $24 \mathrm{~h}$ after instillation. The scoring system for the macroscopic evaluation was performed according to the modified protocol established by Enriquez et al., used by our research group in previous studies [62-64]. The clinical signs observed were corneal opacity, conjunctival alterations, discharge, eyelid swelling and animal discomfort (as shown by intense blinking), and were sorted from 0 to 2 (Table 1).

Table 1. Grading system for in vivo tolerance evaluation signs.

\begin{tabular}{|c|c|c|c|c|c|}
\hline Grade & Discomfort & Cornea & Conjunctiva & Discharge & Lids \\
\hline 1 & Blinking & Mild Opacity & $\begin{array}{l}\text { Mild hyperemia/mild } \\
\text { oedema }\end{array}$ & $\begin{array}{c}\text { Mild discharge } \\
\text { without moistened } \\
\text { hair }\end{array}$ & Mild swelling \\
\hline 2 & $\begin{array}{c}\text { Enhanced } \\
\text { blinking/intense } \\
\text { tearing/vocalizations }\end{array}$ & Intense opacity & $\begin{array}{c}\text { Intense } \\
\text { hyperemia/intense } \\
\text { oedema/haemorrhage }\end{array}$ & $\begin{array}{l}\text { Intense discharge } \\
\text { with moistened hair }\end{array}$ & Obvious swelling \\
\hline
\end{tabular}

\subsection{In Vivo Efficacy Study}

Animals received a single dose $(25 \mu \mathrm{l})$ of the different tested formulations. TM-GNP concentration in each formulation was adjusted to an equivalent concentration of TM $(0.5 \%, 0.25 \%$ or $0.1 \%)$ that resulted $16 \mathrm{mg} / \mathrm{mL}, 8 \mathrm{mg} / \mathrm{mL}$ or $3 \mathrm{mg} / \mathrm{mL}$, respectively. Non-loaded GNP were tested at $16 \mathrm{mg} / \mathrm{mL}$ ( $\mathrm{n}=20$ per group) as control. A marketed formulation (TM $0.5 \%$ ) was employed as a reference. In a second step of the study, in light of the results obtained, TM-GNP ( $3 \mathrm{mg} / \mathrm{mL}$; TM 0.1\%) was suspended in HPMC $0.3 \%$ to determine the efficacy of the nanoparticles in a viscous solution.

To study the time course of the effect of the different formulations, two IOP measurements were taken before any compound was administered (30 min and just before the instillation) to determine basal IOP. Then, measurements were taken at pre-scheduled times $(1,2,3,4,5,6,7,8,12$ and 24 $\mathrm{h}$ after instillation). All measurements were performed with an Icare Tonovet rebound tonometer (Vantaa; Finland). This technique allows the acquisition of IOP values without the administration of topical anaesthesia. The parameters analyzed were the area under the curve (AUC) from 0-12 h, the maximum \% IOP reduction, hypotensive duration of the effect and time where the maximum effect is reached (tmax).

\subsection{Statistical Analysis}

All data are presented as the mean \pm Standard Error (SE). Statistical differences for in vitro tolerance and hypotensive determination at in vivo studies between two mean values were assessed by 
two-tailed students' $t$-test. For comparative purposes of inferiority, equality or superiority, ANOVA between the developed formulations and the manufactured reference formulation have been performed. The software used to perform the mentioned tests were Statgraphics Centurion 18 (Virginia; USA) and Graphpad Prism 6 (San Diego, CA, USA).

\section{Results}

\subsection{Timolol Maleate Loaded Gelatin Nanoparticles Characterization}

TM-GNP presented a round shape according to TEM images (Figure 1), with a mean size of $193.2 \pm 20.7 \mathrm{~nm}$ and 0.011 PDI and a neutral Z-potential $(-0.684 \pm 4.48 \mathrm{mV})$. TM-GNP presented a drug loading of $0.291 \pm 0.019 \mathrm{mg} \mathrm{TM} / \mathrm{mg}$ GNPs $(58.7 \pm 3.8 \%)$.


Figure 1. TEM images of the nanoparticles developed. Image (A) shows gelatin nanoparticles (GNP), whereas images $(\mathbf{B}, \mathbf{C})$ corresponds with TM-GNP.

\subsection{In Vitro Release Studies}

Nanoparticles released the $5.90 \pm 1.04 \%$ of the loading drug in the first $30 \mathrm{~min}$ of release assay in PBS. After that, $80.46 \pm 1.44 \%$ of the total timolol maleate was delivered at the end of the first day of study. The remaining content was sustained and released during the next $24 \mathrm{~h}$ at a rate of $11.14 \%$ 
TM/day (from day 1 to day 2 of the release test) and 1.64\% TM/day from day 2 to day 4 of the release test (Figure 2). When the released media was modified by the inclusion of proteases or MMP-2 similar values were obtained (see values inserted in Table 2 and Figure 2). According to the similarity factor values, similarity was found in the release profile when protease or metalloproteinase was included (f2 = 89 for PBS versus Protease profiles and f2 = 71 for PBS versus MMP-2 profiles) [65].

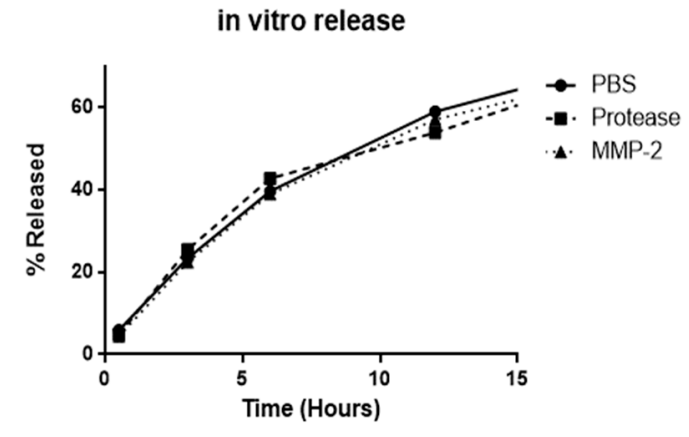

(A)

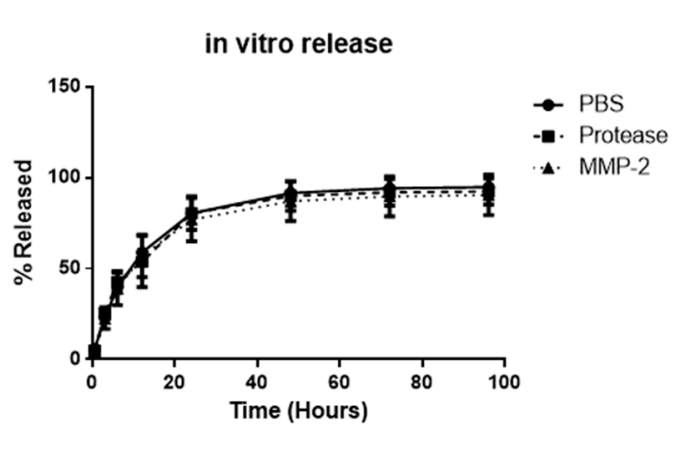

(B)

Figure 2. (A) Release points at 0.5, 3 and $6 \mathrm{~h}$, deviation marks have been removed in order to permit its appreciation (B) Cumulative in vitro release (percentage) of TM for $96 \mathrm{~h}$ ( 5 days) with three different release media PBS, PBS with protease $(60 \mathrm{ng} / \mathrm{mL})$ and PBS with MMP-2 $(60 \mathrm{ng} / \mathrm{mL})$. Each experiment was carried out by quadruplicate.

Table 2. Initial burst and release at $24 \mathrm{~h}$ TM-NPs in the different release media employed (PBS, PBS with protease and PBS with MMP-2).

\begin{tabular}{ccc}
\hline Release Media & Initial Burst $(\mathbf{0 . 5} \mathbf{h})$ & $\mathbf{2 4} \mathbf{h}$ \\
\hline PBS & $5.90 \pm 1.04$ & $80.46 \pm 1.44 \%$ \\
\hline PBS and Protease $(60 \mathrm{ng} / \mathrm{mL})$ & $4.88 \pm 1.29 \%$ & $80.46 \pm 9.17 \%$ \\
\hline PBS and MMP-2 $(60 \mathrm{ng} / \mathrm{mL})$ & $4.50 \pm 0.83 \%$ & $77.00 \pm 11.87 \%$ \\
\hline
\end{tabular}

\subsection{In Vitro and in Vivo Tolerance Studies}

According to the MTT studies, unloaded gelatin nanoparticles up to concentrations of $30 \mathrm{mg} / \mathrm{mL}$ were well tolerated by corneal cells after $1 \mathrm{~h}, 4 \mathrm{~h}$ and $24 \mathrm{~h}$ of contact time (cell viability values higher than $80 \%$ in all cases). However, when particles were loaded with timolol maleate, a dose-dependent reduction of cell viability was observed after $4 \mathrm{~h}$ and $24 \mathrm{~h}$ of exposition. This reduction was also observed for the commercial preparation after $24 \mathrm{~h}$ of contact. TM-GNP at $20 \mathrm{mg} / \mathrm{mL}$ and $10 \mathrm{mg} / \mathrm{mL}$ resulted in viability values higher than $80 \%$ after exposures of $1 \mathrm{~h}$ and $4 \mathrm{~h}$ with a decrease at $24 \mathrm{~h}$. It is worthy to mention that the marketed formulation was less tolerated by corneal cells than $20 \mathrm{mg} / \mathrm{mL}$ TM-GNP, which contained a higher concentration of the active compound (Figure 3).

An acute in vivo tolerance study was performed with non-loaded nanoparticles $(30 \mathrm{mg} / \mathrm{mL})$. Right before the first instillation, rabbits presented no clinical signs and ocular structures were as usual. No corneal discomfort or eyelid inflammation was observed at 3,6 and $24 \mathrm{~h}$ after a single instillation. Some of the treated eyes presented a minimal depot around the rabbit eye for $24 \mathrm{~h}$ after the beginning of the study. The in vivo efficacy studies were performed with the formulation that generated the best results in the in vitro cytotoxicity studies and in vivo tolerance studies, and therefore resulted in the best tolerance. 




(A)

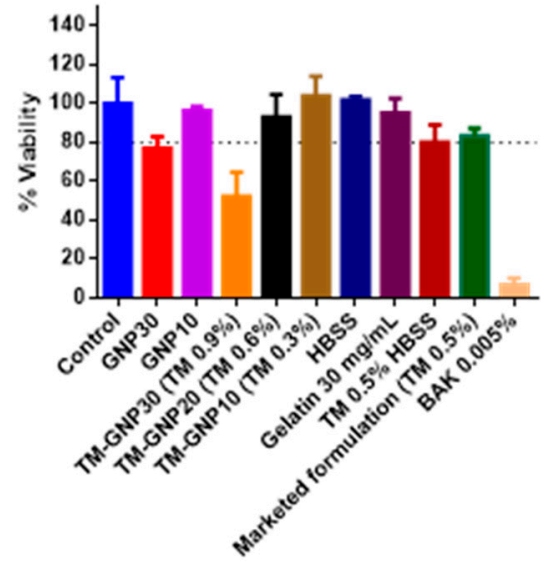

(B)

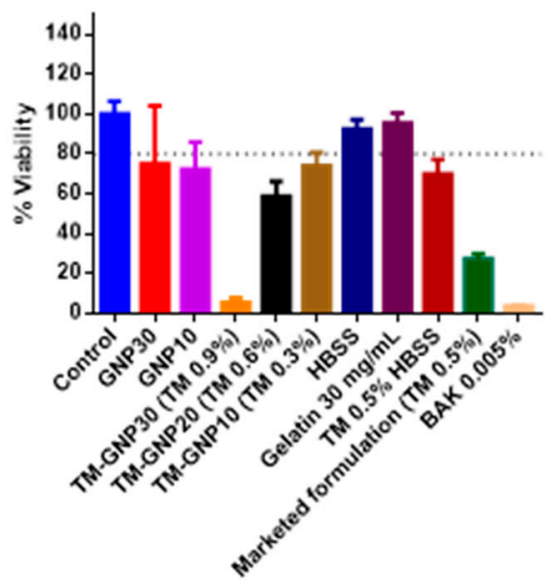

(C)

Figure 3. Human corneal cells (HCEpiC) viability at different exposition times $(1 \mathrm{~h}(\mathbf{A}), 4 \mathrm{~h}$ (B) and $24 \mathrm{~h}(\mathrm{C})$ ). Negative control: cell culture media; GNP30, GNP20 and GNP10 entail unloaded gelatin nanoparticles at 30, 20 and $10 \mathrm{mg} / \mathrm{mL}$, respectively. TM-GNP30, TM-GNP20 and TM-GNP10 indicate timolol maleate gelatin loaded nanoparticles at $30 \mathrm{mg} / \mathrm{mL}, 20 \mathrm{mg} / \mathrm{mL}$ and $10 \mathrm{mg} / \mathrm{mL}$ (equivalent percentage of timolol maleate shown in brackets: $0.9 \%, 0.6 \%$ and $0.3 \%$ ). HBSS: Hank's balanced salt solution; gelatin $30 \mathrm{mg} / \mathrm{mL}$ dissolved in HBSS (raw material), Timolol maleate $0.5 \%$ dissolved in HBSS (raw material), marketed formulation (0.5\%) and positive control BAK $0.005 \%$.

\subsection{In Vivo Efficacy Studies}

IOP measurements were performed at pre-set times from 0 to $24 \mathrm{~h}$ after a single instillation of the different formulations. The empty nanocarrier (non-loaded gelatin nanoparticles (GNP) were tested as control, showing small IOP variations resulting in no significant differences to basal values $(p>0.05)$. For comparison purposes, studies were also performed with a marketed formulation $(0.5 \%)$ used as reference (Figure 4). 


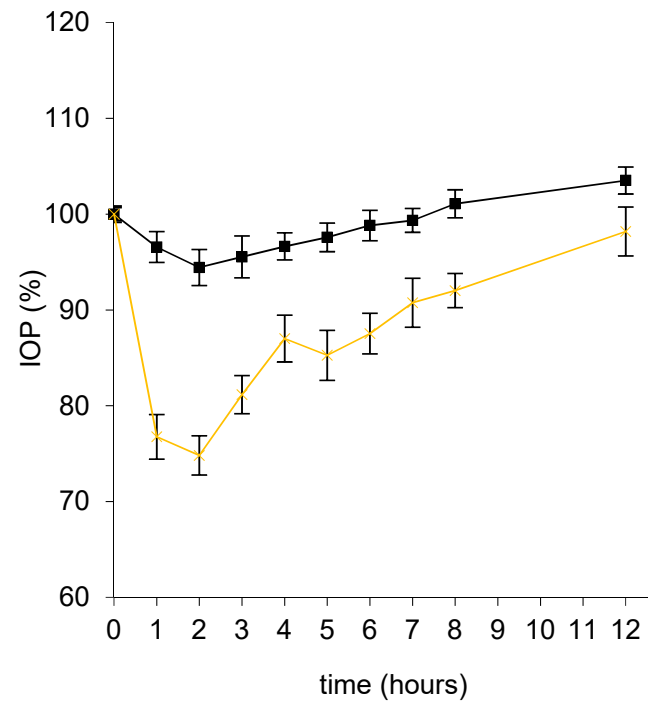

(A)

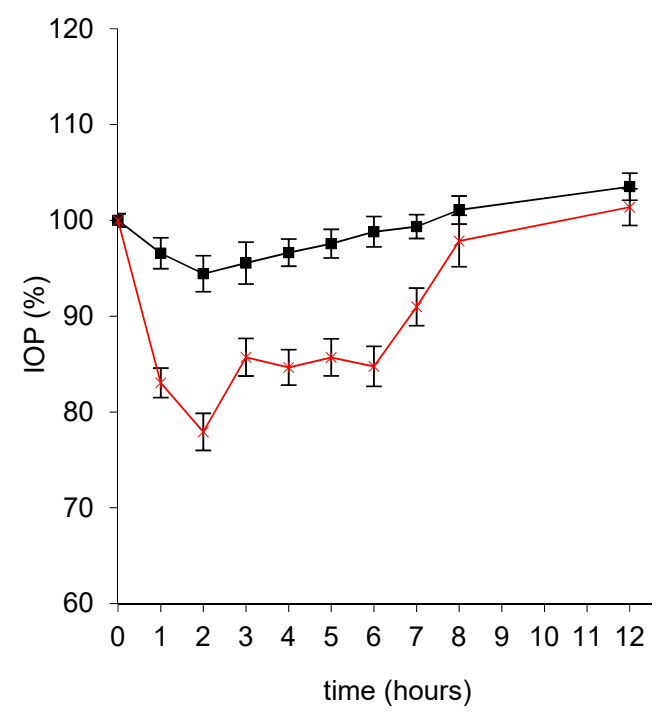

(C)

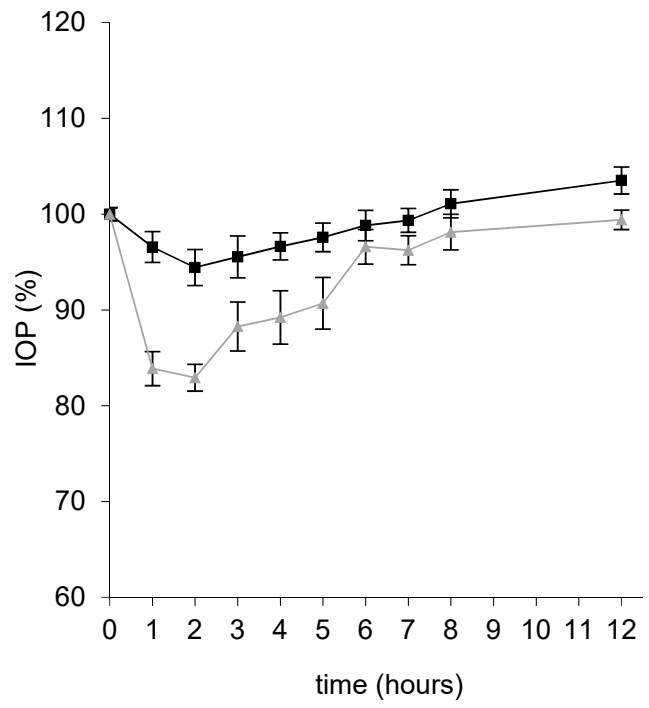

(B)



(D)

Figure 4. Intraocular pressure (IOP) reduction generated by a single instillation of the following formulations: (A) TM-GNP16 (TM 0.5\%), (B) marketed formulation (TM 0.5\%, used as a reference), (C) TMGNP8 (TM 0.25\%) and (D) TMGNP3 (TM 0.1\%). In black, IOP reduction curve of unloaded gelatin nanoparticles used as control.

In a first set of experiments different concentrations of timolol-loaded nanoparticles $(16 \mathrm{mg} / \mathrm{mL}$, $8 \mathrm{mg} / \mathrm{mL}$, and $3 \mathrm{mg} / \mathrm{mL}$ ) corresponding to TM concentrations of $0.5 \%, 0.25 \%$ and $0.1 \%$, respectively were tested and compared with the marketed formulation (timolol maleate content of $0.5 \%$ ) (Figure 4 and Table 3). The loading of TM in gelatin nanoparticles induced an increment in drug efficacy in terms of maximal IOP reduction and also drug bioavailability (expressed as AUC ${ }_{(0-12)}$ ), when TM was administered at the same dose of the marketed formulation ( $p$-values shown in Table 4). 
Table 3. Maximal \% IOP reduction, Maximal $\mathrm{mmHg}$ reduction, $\mathrm{t}_{\max }$, hypotensive effect duration (hours) and the area under the curve AUC (0-12h) from the developed formulations.

\begin{tabular}{cccccc}
\hline Formulation & $\begin{array}{c}\text { Maximal \% } \\
\text { IOP Reduction }\end{array}$ & $\begin{array}{c}\text { Maximal mmHg } \\
\text { Reduction }\end{array}$ & $\mathbf{t}_{\max }$ & $\begin{array}{c}\text { Hypotensive Effect } \\
\text { Duration (hours) }\end{array}$ & AUC (0-12) \\
\hline $\begin{array}{c}\text { Marketed formulation } \\
(\mathrm{TM} \mathrm{0.5 \% )}\end{array}$ & $21.11 \pm 1.72$ & $3.23 \pm 0.26$ & 1.5 & 8 & $83.77 \pm 11.71$ \\
\hline $\begin{array}{c}\text { TM-GNP16 } \\
(\mathrm{TM} \mathrm{0.5 \% )}\end{array}$ & $30.09 \pm 1.85$ & $4.33 \pm 0.30$ & 2.0 & 8 & $143.63 \pm 14.16$ \\
\hline $\begin{array}{c}\text { TM-GNP8 } \\
(\mathrm{TM} \mathrm{0.25 \% )}\end{array}$ & $26.39 \pm 1.38$ & $3.75 \pm 0.23$ & 2.0 & 8 & $124.37 \pm 11.89$ \\
\hline $\begin{array}{c}\text { TM-GNP3 } \\
(\mathrm{TM} \mathrm{0.1 \% )}\end{array}$ & $20.46 \pm 1.41$ & $2.98 \pm 0.20$ & 2.0 & 8 & $102.44 \pm 13.47$ \\
\hline
\end{tabular}

Table 4. $p$-values obtained after one-way ANOVA comparison between the reference commercial formulation and timolol-loaded nanoparticle formulations. $\left({ }^{*}\right.$ significant differences $\left.p<0.05\right)$.

\begin{tabular}{lccc}
\hline & AUC $_{\mathbf{( 0 - 1 2 )}}$ & Maximal mmHg Reduction \% & Maximal mmHg Reduction \\
\hline TM-GNP3 (TM 0.1\%) & $p=0.1581$ & $p=0.9376$ & $p=0.7339$ \\
\hline TM-GNP8 (TM 0.25\%) & $p=0.0075^{*}$ & $p=0.0119^{*}$ & $p=0.0279^{*}$ \\
\hline TM-GNP16 (TM 0.5\%) & $p=0.0009^{*}$ & $p=0.0011^{*}$ & $p=0.0011^{*}$ \\
\hline
\end{tabular}

In fact, it was necessary to reduce nearly five times the concentration of TM-GNP to achieve comparable IOP values with the marketed formulation. On the contrary, the commercial preparation generated a faster onset of action, showing a $t_{\max } 30$ min earlier than TM-GNPs.

In a second set of experiments, the nanoparticle formulation that produced a similar hypotensive effect to the commercial preparation was combined with HPMC: TM-GNP3 (TM 0.1\%) + HPMC 0.3\%. This hybrid system promoted an increment in drug efficacy for all parameters evaluated: Maximal $\%$ IOP reduction (1.5-fold higher than the marketed preparation), Maximal mmHg reduction (1.5-fold higher than the commercial reference), and drug bioavailability expressed as AUC ${ }_{(0-12)}$ (2.5-fold higher than the marketed formulation) these values were statistically significantly higher ( $p$ values at Table 5 ) (Figure 5 and Table 6).



Figure 5. IOP \% profile of the following formulations: (ム) Marketed formulation (TM 0.5\%), (•) TMGNP3 $(0.1 \%),(\times)$ TMGNP3 $(0.1 \%)+$ HPMC $0.3 \%$ and $(\boldsymbol{\square})$ blank gelatin nanoparticles used as control. 
Table 5. $p$-values obtained after one-way ANOVA comparison between the reference marketed formulation and TM-GNP3 with and without viscous HPMC. ${ }^{*}$ significant differences $\left.p<0.001\right)$.

\begin{tabular}{cccc}
\hline & AUC $_{\mathbf{0} \text { (12) }}$ & Maximal mmHg Reduction \% & Maximal mmHg Reduction \\
\hline TM-GNP3 (TM 0.1\%) & $p=0.1581$ & $p=0.9376$ & $p=0.7339$ \\
\hline $\begin{array}{c}\text { TM-GNP3 (TM 0.1\%) } \\
\text { + HPMC 0.3\% }\end{array}$ & $p<0.0001 *$ & $p=0.0007^{*}$ & $p=0.0010^{*}$ \\
\hline
\end{tabular}

Table 6. Maximal \% IOP reduction $\pm \mathrm{SEM} ; \mathrm{t}_{\mathrm{max}}$ acquired by the median of first maximum effect and AUC is the difference of IOP (\%) time curve from $0-12 \mathrm{~h} \pm \mathrm{SE}$.

\begin{tabular}{cccccc}
\hline Formulation & $\begin{array}{c}\text { Maximal \% IOP } \\
\text { Reduction }\end{array}$ & $\begin{array}{c}\text { Maximal mmHg } \\
\text { Reduction }\end{array}$ & $\mathbf{t}_{\text {max }}$ & $\begin{array}{c}\text { Hypotensive Effect } \\
\text { Duration (hours) }\end{array}$ & AUC (0-12) \\
\hline $\begin{array}{c}\text { Marketed formulation } \\
\text { (TM 0.5\%) }\end{array}$ & $21.11 \pm 1.72$ & $3.23 \pm 0.26$ & 1.5 & 8 & $83.77 \pm 11.71$ \\
\hline $\begin{array}{c}\text { TM-GNP3 } \\
(\text { TM 0.1 } \%)\end{array}$ & $20.46 \pm 1.41$ & $2.98 \pm 0.20$ & 2.0 & 8 & $102.44 \pm 13.47$ \\
\hline $\begin{array}{c}\text { TM-GNP3 } \\
\text { (TM 0.1\%) + HPMC 0.3 } \%\end{array}$ & $29.64 \pm 1.60$ & $4.65 \pm 0.24$ & 1.0 & 12 & $213.85 \pm 13.75$ \\
\hline
\end{tabular}

Furthermore, the hypotensive effect reached a maximum value $1 \mathrm{~h}$ after the instillation of TM-GNP3+HPMC and, interestingly, it was maintained for $12 \mathrm{~h}$, instead of $8 \mathrm{~h}$, as observed with the commercial preparation and TM-GNP formulations that did not contain HPMC.

\section{Discussion}

The need for novel drug delivery systems is a major challenge in obtaining safe and effective therapies for managing IOP in glaucoma. However, the ocular surface barriers entail a challenge for drug penetration. To overcome this limitation high drug concentration and frequent instillations are needed, which can lead to important systemic side effects and low patient compliance.

The potential of nanoparticles to decrease the adverse effects associated with beta-blockers drugs in glaucoma have been widely remarked $[50,66,67]$. The present work tries to offer a biodegradable, well tolerated and effective nanoparticulate system to address TM for IOP reduction. With this idea, gelatin was selected as the nanocarrier component because of its well-known biocompatibility [68]. Gelatin can present different bloom index (measured by gel strength) that indicates the amount of triple-helix content, determining mechanical, rheological and thermal properties, as well as gelatin biodegradation that regulates drug release $[66,67]$ Among the different available gelatines, in this work a high Bloom gelatin ( $225 \mathrm{~g}$ bloom values; $50,000-100,000 \mathrm{~g} / \mathrm{mol}$ ) was chosen. This characteristic leads to a raised melting point and enhanced stability [69] and also to a short gelling time heading to rapid nanoparticle formation $[69,70]$. Other authors have also employed GNPs for TM delivery purposes. In some cases, glutaraldehyde has been used as a crosslinked agent [71]. However, in this work, we have employed a less cytotoxic crosslinker to create the gelatin nanogels, glyoxal [59], and an extensive dialysis final step in the nanoparticles manufacturing to guarantee the elimination of any unreacted and undesired compound. Low particle sizes such as those obtained in the present work $(193.2 \pm 20.7 \mathrm{~nm})$ avoid irritation or discomfort over the eye surface [72-74], and also it has been established that this size range can improve drug permeation within the corneal layer [47]. The result of the encapsulation efficiency of TM $(58.7 \pm 3.82 \%)$ can be explained since the near-neutral potential of the particles increases affinity between timolol and the nanoparticle former material gelatin [75]. All these characteristics make the GNP nanoparticles developed in this work very suitable for ocular topical administration in eye drops.

The formulation of gelatin nanoparticles containing the same TM dose as the marketed formulation prepared in this work was able to control in vitro the release of timolol. The release profile was characterized by a fast initial release during the first $24 \mathrm{~h}(80.50 ; 79.22 ; 77.00 \%$ for PBS, Protease and 
MMP-2 media respectively), probably due to the rapid delivery of the drug adsorbed onto the nanoparticle surface [51]. The posterior particles gelling would hinder the drug diffusion from its inner core to the release media leading to a low release fashion extended for three additional days $[76,77]$. In vitro release studies were also performed in media containing protease or MMP-2 at the equivalent concentrations observed on the ocular surface in glaucomatous patients suffering inflammation events [53-55]. According to our data, these nanoparticles were resistant to these media, being able to protect the active compound and to progressively release it even at these conditions, probably due to the high density of the crosslinked gelatin matrix [78].

Although, an important number of different nanodevices composed by diverse materials are being evaluated for topical ocular drug delivery purposes in the past decades, not all of them have been properly tested in terms of ocular tolerance, which is an imperative previous step in order to guarantee good in vivo tolerance of the proposed systems [22]. That is why, in this work, we have in vitro corroborated the selection of nanoparticle concentrations with optimal ocular tolerance. For this purpose, in vitro tolerance studies were performed in order to establish nanoparticles concentrations suitable for in vivo efficacy studies. In vitro tolerance studies showed a concentration-dependent reduction of cell viability for nanoparticles loaded with timolol maleate. Considering that non-loaded nanoparticles and gelatin solution resulted well tolerated even at the highest concentration studied $(30 \mathrm{mg} / \mathrm{mL})$ and that both the timolol maleate solution and the marketed formulation $(0.5 \% \mathrm{TM})$ also showed cell viability reduction after $24 \mathrm{~h}$ of contact, it seems rational to blame the drug and not the polymer for this phenomena. In fact, other authors have already demonstrated that high concentrations of this drug produce a cytotoxic effect in Chang's conjunctival cell line [79]. The in vivo acute tolerance test performed confirmed that a high concentration $(30 \mathrm{mg} / \mathrm{mL})$ of non-loaded gelatin nanoparticles were well tolerated, supporting the suitability of the drug delivery system proposed in this work. Unfortunately, the exposure of animals' eyes to very frequent doses of timolol (an instillation each $30 \mathrm{~min}$ ) was not ethically possible, so this in vivo acute tolerance study could not be performed with loaded nanoparticles. At this point it was reasonable to limit the use of timolol maleate loaded nanoparticles at concentrations lower than $20 \mathrm{mg} / \mathrm{mL}$ (well tolerated in cell cultures) for in vivo efficacy studies. In fact, in order to mimic the clinical treatments currently performed with the commercial preparation $(0.5 \% \mathrm{TM})$ the highest concentration of TM-GNP (in vivo tested) was fixed at $16 \mathrm{mg} / \mathrm{mL}(0.5 \% \mathrm{TM})$ for efficacy studies. Additionally, $8 \mathrm{mg} / \mathrm{mL}$ and $3 \mathrm{mg} / \mathrm{mL}$ TM-loaded nanoparticles concentrations were also tested. According to our results, the inclusion of timolol maleate in gelatin nanoparticles promoted a higher ocular bioavailability in comparison to its administration in the marketed formulation (1.7-fold increments of TM-GNP16 versus the commercial preparation). In fact, the administration of only $0.1 \%$ of timolol maleate included in nanoparticles ( $3 \mathrm{mg}$ of nanoparticles $/ \mathrm{mL}$ ) offered the same hypotensive effects in terms of maximal \% IOP reduction and maximal $\mathrm{mmHg}$ reduction and also of drug bioavailability (expressed as AUC $\left.{ }_{(0-12)}\right)$ than the marketed preparation. The employment of 5-fold less TM to reach the same hypotensive effect might be very interesting in clinic. Accordingly, several studies have demonstrated that ophthalmic treatments with TM $0.1 \%$ achieve considerably lower plasma concentrations compared to TM $0.5 \%$ [80-82] and thus, reducing the systemic effects after administration of the commercial formulation. In the present study the commercial formulation (TM $0.5 \%$ ) was only able to reach a $21 \%$ IOP reduction in normotensive rabbits, meanwhile, TM-GNP8 (TM $0.25 \%$ ) was able to achieve a $26 \%$ decrease including half of the dose and TM-GNP16 (TM 0.5\%) promoted IOP decrease over 30\%. Significant differences have been observed in all the cases $(p<0.05)$. The aforementioned results could be explained by the mucoadhesive properties of gelatin, leading to a higher retention time on the ocular surface [48] and higher corneal penetration of the nanoparticulate system $[47,51,83]$. These data demonstrate that timolol loaded gelatin nanoparticles can result in a very promising strategy for ocular delivery of hypotensive compounds and that, interestingly, target pressure can be modulated employing different concentrations of TM-GNP. In all these efficacy studies, the hypotensive effect was observed for 8 $h$ after a single administration. The combination of TM-GNP3 with a viscous solution composed 
by HPMC $0.3 \%$ statistically improved $(p<0.05)$ not only the IOP reduction but also the reaching values of $30 \%$ and the maximal mmHg reduction, as well as faster maximal action $\left(t_{\max }=1 \mathrm{~h}\right)$. Furthermore, the hypotensive effect was extended for four additional hours reaching a total of 12 $\mathrm{h}$ of pharmacological activity after a single instillation and a raised ocular bioavailability (2.5-fold higher than the one observed for the marketed formulation), due to the beneficial combination of nanosystems and the viscous agent [24]. The incorporation of HPMC has the effect of not only enhancing efficacy over TM-GNPs, but also it has been widely demonstrated that the incorporation of HPMC in antiglaucomatous eye drops increases patient compliance. This fact has been explained due to the recession of diverse side effects associated with chronic eye drops administrations such as DED $[84,85]$.

\section{Conclusions}

Gelatin nanoparticles alone or in combination with viscous polymeric solutions have been demonstrated as a promising alternative to deliver beta-blockers for controlling IOP in glaucoma, both in the presence or absence of damaged ocular surface and can be an interesting tool for personalized treatments. The platform created by the combination of gelatin nanoparticles and well tolerated viscous agents can not only lead to higher patient compliance and medical adherence, but also can offer additional benefits in terms of tolerance for chronic treatments.

Author Contributions: Conceptualization, R.H.-V., S.E.-P., V.A.-G., I.B.-O. and I.M.-M.; methodology, S.E.-P., J.J.L.-C., I.B.-O., V.A.-G., R.H.-V. and I.M.-M.; software, S.E.-P., J.J.L.-C.; validation, I.M.-M., S.E.-P. and V.A.-G.; formal analysis, V.A.-G., S.E.-P., I.B.-O.; investigation, S.E.-P., J.J.L.-C., V.A.-G., I.B.-O., I.M.-M. and R.H.-V.; resources, I.M.-M. and R.H.-V.; data curation, I.M.-M., V.A.-G. and I.B.-O.; writing-original draft preparation, S.E.-P.; writing-review and editing, S.E.-P., V.A.-G., I.B-O.; visualization, R.H.-V., I.M.-M.; supervision, R.H.-V. and I.M.-M.; project administration, I.M.-M. and R.H.-V.; funding acquisition, I.B.-O., I.M.-M., R.H.-V. All authors have read and agreed to the published version of the manuscript.

Funding: This research was funded by Research Group UCM 920415 (InnOftal). MINECO/AEI/FEDER, UE (MAT2017-83858-C2-1-R), MSCA-RISE-3DNEONET/734907, ISCII-FEDER RETICS (OFTARED) (RD16/0008/0009 and RD16/0008/0004), FEDER-CICYT CIS- PI17/00079 and PI17/000466.

Acknowledgments: Authors are grateful to the technical TEM assistance of the Centro de Microscopía Electrónica Luis Bru (CAI, UCM) and CAI Alcala de Henares for cell culture tolerance studies development.

Conflicts of Interest: The authors declare no conflict of interest.

\section{References}

1. Das Gupta, B.K. Glaucoma. J. Indian Med. Assoc. 1955, 25, 668-674.

2. Davis, B.; Crawley, L.; Pahlitzsch, M.; Javaid, F.; Cordeiro, M.F. Glaucoma: the retina and beyond. Acta Neuropathol. 2016, 132, 807-826. [CrossRef] [PubMed]

3. Doozandeh, A.; Yazdani, S. Neuroprotection in Glaucoma. J. Ophthalmic Vis. Res. 2016, 11, $209-220$. [CrossRef]

4. Schmidl, D.; Schmetterer, L.; Garhöfer, G.; Popa-Cherecheanu, A. Pharmacotherapy of Glaucoma. J. Ocul. Pharmacol. Ther. 2015, 31, 63-77. [CrossRef] [PubMed]

5. Liu, H.K.; Chiou, G.C.Y.; Garg, L.C. Ocular Hypotensive Effects of Timolol in Cat Eyes. Arch. Ophthalmol. 1980, 98, 1467-1469. [CrossRef] [PubMed]

6. Martinez-De-La-Casa, J.M.; Rayward, O.; Saenz-Frances, F.; Santos-Bueso, E.; Mendez-Hernandez, C.; Herrero-Vanrell, R.; Feijoo, J.G.; García-Sánchez, J. Effects of corneal thickness on the intraocular penetration of travoprost $0.004 \%$. Eye 2012, 26, 972-975. [CrossRef]

7. Ramsay, E.; Del Amo, E.M.; Toropainen, E.; Tengvall-Unadike, U.; Ranta, V.-P.; Urtti, A.; Ruponen, M. Corneal and conjunctival drug permeability: Systematic comparison and pharmacokinetic impact in the eye. Eur. J. Pharm. Sci. 2018, 119, 83-89. [CrossRef]

8. Goyal, G.; Garg, T.; Rath, G.; Goyal, A.K. Current nanotechnological strategies for treating glaucoma. Crit. Rev. Ther. Drug Carr. Syst. 2014, 31, 365-405. [CrossRef]

9. Cohen, L.P.; Pasquale, L.R. Clinical Characteristics and Current Treatment of Glaucoma. Cold Spring Harb. Perspect. Med. 2014, 4, a017236. [CrossRef] 
10. Lowenthal, D.T.; Pitone, J.M.; Affrime, M.B.; Shirk, J.; Busby, P.; Kim, K.E.; Nancarrow, J.; Swartz, C.D.; Onesti, G. Timolol kinetics in chronic renal insufficiency. Clin. Pharmacol. Ther. 1978, 23, 606-615. [CrossRef]

11. Waterman, H.; Evans, J.; Gray, T.; Henson, D.; Harper, R.A. Interventions for improving adherence to ocular hypotensive therapy. Cochrane Database Syst. Rev. 2013, 4, CD006132. [CrossRef] [PubMed]

12. Zimmerman, T.J.; Baumann, J.D.; Hetherington, J. Side effects of timolol. Surv. Ophthalmol. 1983, 28, $243-249$. [CrossRef]

13. Mäenpää, J.; Pelkonen, O. Cardiac safety of ophthalmic timolol. Expert Opin. Drug Saf. 2016, 15, 1549-1561. [CrossRef] [PubMed]

14. Bravo-Osuna, I.; Vicario-De-La-Torre, M.; Guerrero, V.A.; Sánchez-Nieves, J.; Guzman-Navarro, M.; De La Mata, F.J.; Gómez, R.; Heras, B.D.L.; Argüeso, P.; Ponchel, G.; et al. Novel Water-Soluble Mucoadhesive Carbosilane Dendrimers for Ocular Administration. Mol. Pharm. 2016, 13, 2966-2976. [CrossRef]

15. Gómez-Ballesteros, M.; Guerrero, V.A.; Parra, F.J.; Marinich, J.; Heras, B.D.L.; Martínez, I.T.M.; Vázquez-Lasa, B.; Del Barrio, J.S.R.; Herrero-Vanrell, R. Amphiphilic Acrylic Nanoparticles Containing the Poloxamer Star Bayfit ${ }^{\circledR}$ 10WF15 as Ophthalmic Drug Carriers. Polymer 2019, 11, 1213. [CrossRef]

16. Katiyar, S.; Pandit, J.; Mondal, R.S.; Mishra, A.K.; Chuttani, K.; Aqil, M.; Ali, A.; Sultana, Y. In situ gelling dorzolamide loaded chitosan nanoparticles for the treatment of glaucoma. Carbohydr. Polym. 2014, 102, 117-124. [CrossRef]

17. Gautam, N.; Kesavan, K. Development of microemulsions for ocular delivery. Ther. Deliv. 2017, 8, 313-330. [CrossRef]

18. Hui, A. Contact lenses for ophthalmic drug delivery. Clin. Exp. Optom. 2017, 100, 494-512. [CrossRef]

19. Bravo-Osuna, I.; Guerrero, V.A.; Arranz-Romera, A.; Pérez, S.E.; Martínez, I.T.M.; Herrero-Vanrell, R. Microspheres as intraocular therapeutic tools in chronic diseases of the optic nerve and retina. Adv. Drug Deliv. Rev. 2018, 126, 127-144. [CrossRef]

20. Janagam, D.R.; Wu, L.; Lowe, T.L. Nanoparticles for drug delivery to the anterior segment of the eye. Adv. Drug Deliv. Rev. 2017, 122, 31-64. [CrossRef]

21. Ribeiro, A.M.; Figueiras, A.; Veiga, F. Improvements in Topical Ocular Drug Delivery Systems: Hydrogels and Contact Lenses. J. Pharm. Pharm. Sci. 2015, 18, 683-695. [CrossRef]

22. Herrero-Vanrell, R.; De La Torre, M.V.; Guerrero, V.A.; Barbosa-Alfaro, D.; Martínez, I.T.M.; Bravo-Osuna, I. Nano and microtechnologies for ophthalmic administration, an overview. J. Drug Deliv. Sci. Technol. 2013, 23, 75-102. [CrossRef]

23. Patel, A.; Cholkar, K.; Agrahari, V.; Mitra, A.K. Ocular drug delivery systems: An overview. World J. Gastrointest. Pharmacol. Ther. 2013, 2, 47-64. [CrossRef] [PubMed]

24. Guerrero, V.A.; Vicario-De-La-Torre, M.; Herrero-Vanrell, R.; Martínez, I.T.M.; Benítez-Del-Castillo, J.M.; Feijoo, J.G. Comparison of the In Vitro Tolerance and In Vivo Efficacy of Traditional Timolol Maleate Eye Drops versus New Formulations with Bioadhesive Polymers. Investig. Opthalmol. Vis. Sci. 2011, 52, 3548-3556. [CrossRef] [PubMed]

25. Le Bourlais, C.; Acar, L.; Zia, H.; Sado, P.A.; Needham, T.; Leverge, R. Ophthalmic drug delivery systems-Recent advances. Prog. Retin. Eye Res. 1998, 17, 33-58. [CrossRef]

26. Greaves, J.L.; Wilson, C.G. Treatment of diseases of the eye with mucoadhesive delivery systems. Adv. Drug Deliv. Rev. 1993, 11, 349-383. [CrossRef]

27. Ludwig, A. The use of mucoadhesive polymers in ocular drug delivery. Adv. Drug Deliv. Rev. 2005, 57, 1595-1639. [CrossRef]

28. Khutoryanskiy, V.V. Advances in Mucoadhesion and Mucoadhesive Polymers. Macromol. Biosci. 2010, 11, 748-764. [CrossRef]

29. Snibson, G.R.; Greaves, J.L.; Soper, N.D.W.; Tiffany, J.M.; Wilson, C.G.; Bron, A.J. Ocular Surface Residence Times of Artificial Tear Solutions. Cornea 1992, 11, 288-293. [CrossRef]

30. Tighsazzadeh, M.; Mitchell, J.C.; Boateng, J. Development and evaluation of performance characteristics of timolol-loaded composite ocular films as potential delivery platforms for treatment of glaucoma. Int. J. Pharm. 2019, 566, 111-125. [CrossRef]

31. Kouchak, M.; Mahmoodzadeh, M.; Farrahi, F. Designing of a pH-Triggered Carbopol ${ }^{\circledR} / \mathrm{HPMC}$ In Situ Gel for Ocular Delivery of Dorzolamide HCl: In Vitro, In Vivo, and Ex Vivo Evaluation. AAPS PharmSciTech 2019, 20, 210. [CrossRef] [PubMed] 
32. White, C.J.; Thomas, C.R.; Byrne, M.E. Bringing comfort to the masses: A novel evaluation of comfort agent solution properties. Contact Lens Anterior Eye 2014, 37, 81-91. [CrossRef] [PubMed]

33. Zhang, X.; Vadoothker, S.; Munir, W.M.; Saeedi, O. Ocular Surface Disease and Glaucoma Medications. Eye Contact Lens Sci. Clin. Pract. 2019, 45, 11-18. [CrossRef] [PubMed]

34. Wang, Y.; Xu, X.; Gu, Y.; Cheng, Y.; Cao, F. Recent advance of nanoparticle-based topical drug delivery to the posterior segment of the eye. Expert Opin. Drug Deliv. 2018, 15, 687-701. [CrossRef] [PubMed]

35. Krishnaswami, V.; Kandasamy, R.; Alagarsamy, S.; Palanisamy, R.; Natesan, S. Biological macromolecules for ophthalmic drug delivery to treat ocular diseases. Int. J. Boil. Macromol. 2018, 110, 7-16. [CrossRef] [PubMed]

36. Zhou, H.-Y.; Hao, J.-L.; Wang, S.; Zheng, Y.; Zhang, W. Nanoparticles in the ocular drug delivery. Int. J. Ophthalmol. 2013, 6, 390-396.

37. Silva, M.M.; Calado, R.; Marto, J.; Bettencourt, A.F.; Almeida, A.; Gonçalves, L.M. Chitosan Nanoparticles as a Mucoadhesive Drug Delivery System for Ocular Administration. Mar. Drugs 2017, 15, 370. [CrossRef]

38. Ibrahim, M.M.; Abd-Elgawad, A.-E.H.; Soliman, O.A.-E.; Jablonski, M.M. Stability and Ocular Pharmacokinetics of Celecoxib-Loaded Nanoparticles Topical Ophthalmic Formulations. J. Pharm. Sci. 2016, 105, 3691-3701. [CrossRef]

39. Yang, H.; Tyagi, P.; Kadam, R.S.; Holden, C.A.; Kompella, U.B. Hybrid Dendrimer Hydrogel/PLGA Nanoparticle Platform Sustains Drug Delivery for One Week and Antiglaucoma Effects for Four Days Following One-Time Topical Administration. ACS Nano 2012, 6, 7595-7606. [CrossRef]

40. Warsi, M.H.; Anwar, M.; Garg, V.; Jain, G.K.; Talegaonkar, S.; Ahmad, F.J.; Khar, R.K. Dorzolamide-loaded PLGA/vitamin E TPGS nanoparticles for glaucoma therapy: Pharmacoscintigraphy study and evaluation of extended ocular hypotensive effect in rabbits. Colloids Surf. B Biointerfaces 2014, 122, 423-431. [CrossRef]

41. De La Fuente, M.; Raviña, M.; Paolicelli, P.; Sanchez, A.; Seijo, B.; Alonso, M.J. Chitosan-based nanostructures: A delivery platform for ocular therapeutics. Adv. Drug Deliv. Rev. 2010, 62, 100-117. [CrossRef] [PubMed]

42. De La Fuente, M.; Seijo, B.; Alonso, M.J. Novel Hyaluronic Acid-Chitosan Nanoparticles for Ocular Gene Therapy. Investig. Opthalmol. Vis. Sci. 2008, 49, 2016-2024. [CrossRef] [PubMed]

43. Wadhwa, S.; Paliwal, R.; Paliwal, S.R.; Vyas, S.P. Hyaluronic acid modified chitosan nanoparticles for effective management of glaucoma: development, characterization, and evaluation. J. Drug Target. 2009, 18, $292-302$. [CrossRef] [PubMed]

44. Foox, M.; Zilberman, M. Drug delivery from gelatin-based systems. Expert Opin. Drug Deliv. 2015, 12, 1-17. [CrossRef] [PubMed]

45. Echave, M.C.; Burgo, L.S.; Pedraz, J.L.; Orive, G.; Echave, M.C. Gelatin as Biomaterial for Tissue Engineering. Curr. Pharm. Des. 2017, 23, 3567-3584. [CrossRef] [PubMed]

46. Lu, J.; Shi, M.; Shoichet, M.S. Click Chemistry Functionalized Polymeric Nanoparticles Target Corneal Epithelial Cells through RGD-Cell Surface Receptors. Bioconjugate Chem. 2009, 20, 87-94. [CrossRef]

47. Mahaling, B.; Katti, D.S. Understanding the influence of surface properties of nanoparticles and penetration enhancers for improving bioavailability in eye tissues in vivo. Int. J. Pharm. 2016, 501, 1-9. [CrossRef]

48. Leucuta, S.E. The kinetics of in vitro release and the pharmacokinetics of miotic response in rabbits of gelatin and albumin microspheres with pilocarpine. Int. J. Pharm. 1989, 54, 71-78. [CrossRef]

49. Vandervoort, J.; Ludwig, A. Preparation and evaluation of drug-loaded gelatin nanoparticles for topical ophthalmic use. Eur. J. Pharm. Biopharm. 2004, 57, 251-261. [CrossRef]

50. Shokry, M.; Hathout, R.M.; Mansour, S. Exploring gelatin nanoparticles as novel nanocarriers for Timolol Maleate: Augmented in-vivo efficacy and safe histological profile. Int. J. Pharm. 2018, 545, 229-239. [CrossRef]

51. Mahor, A.; Prajapati, S.K.; Verma, A.; Gupta, R.; Iyer, A.K.; Kesharwani, P. Moxifloxacin loaded gelatin nanoparticles for ocular delivery: Formulation and in vitro, in vivo evaluation. J. Colloid Interface Sci. 2016, 483, 132-138. [CrossRef] [PubMed]

52. Zorzi, G.K.; Contreras-Ruiz, L.; Párraga, J.E.; López-García, A.; Bello, R.; Diebold, Y.; Seijo, B.; Sanchez, A. Expression of MUC5AC in Ocular Surface Epithelial Cells Using Cationized Gelatin Nanoparticles. Mol. Pharm. 2011, 8, 1783-1788. [CrossRef] [PubMed]

53. Sakimoto, T.; Shoji, J.; Kanno, H.; Sawa, M. Gelatinase Expression in Ocular Surface Disorders. Jpn. J. Ophthalmol. 2004, 48, 17-22. [CrossRef] [PubMed] 
54. Sahay, P.; Rao, A.; Padhy, D.; Sarangi, S.; Das, G.; Reddy, M.M.; Modak, R. Functional Activity of Matrix Metalloproteinases 2 and 9 in Tears of Patients with Glaucoma. Investig. Opthalmol. Vis. Sci. 2017, 58, 106. [CrossRef]

55. Määttä, M.; Tervahartiala, T.; Harju, M.; Airaksinen, J.; Autio-Harmainen, H.; Sorsa, T. Matrix metalloproteinases and their tissue inhibitors in aqueous humor of patients with primary open-angle glaucoma, exfoliation syndrome, and exfoliation glaucoma. J. Glaucoma 2005, 14, 64-69.

56. Boiero, C.; Allemandi, D.; Longhi, M.R.; Llabot, J.M. RP-HPLC method development for the simultaneous determination of timolol maleate and human serum albumin in albumin nanoparticles. J. Pharm. Biomed. Anal. 2015, 111, 186-189. [CrossRef]

57. Kommareddy, S.; Amiji, M.M. Preparation and loading of gelatin nanoparticles. CSH Protoc. 2008, 2008, 4885. [CrossRef]

58. Qin, Z.; Joo, J.; Gu, L.; Sailor, M.J. Porous Films: Size Control of Porous Silicon Nanoparticles by Electrochemical Perforation Etching (Part. Part. Syst. Charact. 2/2014). Part. Part. Syst. Charact. 2014, 31, 171. [CrossRef]

59. Garcia-Valldecabres, M.; López-Alemany, A.; Refojo, M.F. pH stability of ophthalmic solutions. Optom. J. Am. Optom. Assoc. 2004, 75, 161-168. [CrossRef]

60. Kumar, P.; Nagarajan, A.; Uchil, P.D. Analysis of Cell Viability by the MTT Assay. Cold Spring Harb. Protoc. 2018, 2018, 095505. [CrossRef]

61. Baudouin, C.; Labbe, A.; Liang, H.; Pauly, A.; Baudouin, C. Preservatives in eyedrops: The good, the bad and the ugly. Prog. Retin. Eye Res. 2010, 29, 312-334. [CrossRef]

62. Enríquez-De-Salamanca, A. Chitosan Nanoparticles as a Potential Drug Delivery System for the Ocular Surface: Toxicity, Uptake Mechanism and In Vivo Tolerance. Investig. Opthalmol. Vis. Sci. 2006, 47, 1416-1425. [CrossRef] [PubMed]

63. Acar, D.; Martínez, I.T.M.; Gómez-Ballesteros, M.; Guzman-Navarro, M.; Benítez-Del-Castillo, J.M.; Herrero-Vanrell, R. Novel liposome-based and in situ gelling artificial tear formulation for dry eye disease treatment. Contact Lens Anterior Eye 2017, 41, 93-96. [CrossRef]

64. Vicario-De-La-Torre, M.; Benítez-Del-Castillo, J.M.; Vico, E.; Guzman-Navarro, M.; Heras, B.D.L.; Herrero-Vanrell, R.; Martínez, I.T.M. Design and Characterization of an Ocular Topical Liposomal Preparation to Replenish the Lipids of the Tear Film. Investig. Opthalmol. Vis. Sci. 2014, 55, 7839-7847. [CrossRef] [PubMed]

65. Shah, V.P.; Tsong, Y.; Sathe, P.; Liu, J.-P. In Vitro Dissolution Profile Comparison-Statistics and Analysis of the Similarity Factor, f2. Pharm. Res. 1998, 15, 889-896. [CrossRef] [PubMed]

66. Zhao, R.; Li, J.; Wang, J.; Yin, Z.; Zhu, Y.; Liu, W. Development of Timolol-Loaded Galactosylated Chitosan Nanoparticles and Evaluation of Their Potential for Ocular Drug Delivery. AAPS PharmSciTech 2017, 18, 997-1008. [CrossRef] [PubMed]

67. Ilka, R.; Mohseni, M.; Kianirad, M.; Naseripour, M.; Ashtari, K.; Mehravi, B. Nanogel-based natural polymers as smart carriers for the controlled delivery of Timolol Maleate through the cornea for glaucoma. Int. J. Boil. Macromol. 2018, 109, 955-962. [CrossRef]

68. Hathout, R.M.; Omran, M.K. Gelatin-based particulate systems in ocular drug delivery. Pharm. Dev. Technol. 2015, 21, 379-386. [CrossRef] [PubMed]

69. Segtnan, V.H.; Isaksson, T. Temperature, sample and time dependent structural characteristics of gelatine gels studied by near infrared spectroscopy. Food Hydrocoll. 2004, 18, 1-11. [CrossRef]

70. Kempka, A.P.; Souza, S.G.; De Souza, A.A.U.; Prestes, R.C.; Ogliari, D. Influence of bloom number and plastifiers on gelatin matrices produced for enzyme immobilization. Braz. J. Chem. Eng. 2014, 31, 95-108. [CrossRef]

71. Coester, K.L.C.J. Gelatin nanoparticles by two step desolvation a new preparation method, surface modifications and cell uptake. J. Microencapsul. 2000, 17, 187-193. [PubMed]

72. Huang, H.-Y.; Wang, M.-C.; Chen, Z.-Y.; Chiu, W.-Y.; Chen, K.-H.; Lin, I.-C.; Yang, W.-C.V.; Wu, C.-C.; Tseng, C.-L. Gelatin-epigallocatechin gallate nanoparticles with hyaluronic acid decoration as eye drops can treat rabbit dry-eye syndrome effectively via inflammatory relief. Int. J. Nanomed. 2018, 13, 7251-7273. [CrossRef] [PubMed] 
73. Qaddoumi, M.G.; Ueda, H.; Yang, J.; Davda, J.; Labhasetwar, V.; Lee, V. The characteristics and mechanisms of uptake of PLGA nanoparticles in rabbit conjunctival epithelial cell layers. Pharm. Res. 2004, 21, 641-648. [CrossRef] [PubMed]

74. Calvo, P.; Alonso, M.J.; Robinson, J.R.; Vila-Jato, J.L. Improved Ocular Bioavailability of Indomethacin by Novel Ocular Drug Carriers. J. Pharm. Pharmacol. 1996, 48, 1147-1152. [CrossRef]

75. Azarmi, S.; Huang, Y.; Chen, H.; A McQuarrie, S.; Abrams, D.; Roa, W.H.; Finlay, W.H.; Miller, G.G.; Löbenberg, R. Optimization of a two-step desolvation method for preparing gelatin nanoparticles and cell uptake studies in 143B osteosarcoma cancer cells. J. Pharm. Pharm. Sci. 2006, 9, 124-132.

76. Sanzgiri, Y.D.; Maschi, S.; Crescenzi, V.; Callegaro, L.; Topp, E.M.; Stella, V.J. Gellan-based systems for ophthalmic sustained delivery of methylprednisolone. J. Control. Release 1993, 26, 195-201. [CrossRef]

77. Cohen, S.; Lobel, E.; Trevgoda, A.; Peled, Y. A novel in situ-forming ophthalmic drug delivery system from alginates undergoing gelation in the eye. J. Control. Release 1997, 44, 201-208. [CrossRef]

78. Ahsan, S.M.; Rao, C.M. The role of surface charge in the desolvation process of gelatin: implications in nanoparticle synthesis and modulation of drug release. Int. J. Nanomed. 2017, 12, 795-808. [CrossRef]

79. De Saint Jean, M.; Debbasch, C.; Brignole, F.; Rat, P.; Warnet, J.M.; Baudouin, C. Toxicity of preserved and unpreserved antiglaucoma topical drugs in an in vitro model of conjunctival cells. Curr. Eye Res. 2000, 20, 85-94. [CrossRef]

80. Uusitalo, H.; Niño, J.; Tahvanainen, K.; Turjanmaa, V.; Ropo, A.; Tuominen, J.; Kähönen, M. Efficacy and systemic side-effects of topical $0.5 \%$ timolol aqueous solution and $0.1 \%$ timolol hydrogel. Acta Ophthalmol. Scand. 2005, 83, 723-728. [CrossRef]

81. Korte, J.-M.; Kaila, T.; Saari, M.K. Systemic bioavailability and cardiopulmonary effects of $0.5 \%$ timolol eyedrops. Graefe's Arch. Clin. Exp. Ophthalmol. 2002, 240, 430-435. [CrossRef] [PubMed]

82. Tamaki, Y.; Araie, M.; Tomita, K.; Nagahara, M.; Tomidokoro, A. Effect of topical beta-blockers on tissue blood flow in the human optic nerve head. Curr. Eye Res. 1997, 16, 1102-1110. [CrossRef] [PubMed]

83. Amit, C.; Muralikumar, S.; Janaki, S.; Lakshmipathy, M.; Therese, K.L.; Vetrivel, U.; Padmanabhan, P.; Narayanan, J.; Therese, K.L. Designing and enhancing the antifungal activity of corneal specific cell penetrating peptide using gelatin hydrogel delivery system. Int. J. Nanomed. 2019, 14, 605-622. [CrossRef] [PubMed]

84. Wegener, A.R.; Meyer, L.M.; Schönfeld, C.-L. Effect of Viscous Agents on Corneal Density in Dry Eye Disease. J. Ocul. Pharmacol. Ther. 2015, 31, 504-508. [CrossRef] [PubMed]

85. Zheng, X.; Goto, T.; Ohashi, Y. Comparison of In Vivo Efficacy of Different Ocular Lubricants in Dry Eye Animal Models. Investig. Opthalmol. Vis. Sci. 2014, 55, 3454-3460. [CrossRef] [PubMed] 